\title{
ЗАДУЖБИНЕ И ЗАДУЖБИНАРИ У СРПСКОЈ ПРАВОСЛАВНОЈ ЕПАРХИЈИ ТЕМИШВАРСКОЈ
}

\begin{abstract}
Задужбинарство као посебан вид доброчинства итекако је био присутан у животу српске заједнице. Задужбине су пример љубави и поштовања појединаца према своме национу и према духовном и интелектуалном узрастању српске омладине и интелектуалаца. Времена која су уследила после Другог светског рата, умањила су интересовање јавности за овај вид доброчинства, те је и судбина ових фондова постала неизвесна све док се они потпуно нису угасили. Данас, када их више нема, о њима најбоље сведоче учињена добра дела и значај којег су имале у животу Срба пречана. Архивска грађа, као и остала богата библиографија, пружају реалну могућност да се прикажу доброчинства ових задужбина и њихових покретача, као феномену од изузетног значаја у српском народу. Остављајући своје задужбине онима који ће после њих на свету долазити, задужбинари су трајно уградили себе у српску историју. Свесни њихове пресудне улоге у датом времену и простору, не смемо занемарити труд оних који су самоодрицањем, љубављу према народу и ближњима и племенитим осећањима, те сматрамо за нашу дужност да њихова бесмртна дела објавимо јавности у знак поштовања и вечите захвалности.
\end{abstract}

Кључне речи: фонд, заклада, задужбина, Темишвар, Арад.

\section{Мецене, филантропи и добротвори}

Задужбинарство код Срба заузима значајно место у историји нашег народа, а историчари су овом феномену поклонили посебну пажњу у свом истраживачком раду³. Задужбинарство предпоставља сваки облик помоћи којег

\footnotetext{
${ }^{1}$ sasa.iasin@e-uvt.ro; isidora_iasin@yahoo.com

${ }^{2}$ Рад је настао у оквиру истраживачког пројекта Центра за научна истраживања Савеза Срба у Румунији.

${ }^{3}$ Славко Вајиновић, Задужбинарство код Срба, Вукова задужбина, Београд, Прометеј, Нови Сад, 2012; Радомир М Милошевић, Црквено задужбинарство код Срба, Храм Светог Апостола Луке, 2005; Радош Љушић, Србија XIX века, Војна књига, Београд, 1994; Vasa Lupulovici, Viața bisericească a sârbilor din Banat între anii 1865 - 1918, Presa universitară clujeană, 2009; Методије Марковић, Небојша Ђокић, Црква Празник Светих Апостола Петра и Павла (Петровдан) у Араду до Првог светског рата - прилог историји, у Митолошки зборник 43, Рача 2020, pp. 341-354; Младена Прелић, (Н)и овде (н)и тамо:
} 
су појединци или група појединаца, ради остварења корисних друштвених циљева положили као део своје заоставштине или своју последњу жељу, коју је сам задужбинар осмислио, одредио и вредновао. Задужбинарство међу Србима пречанима има своју дугу историју, а црпи своје постојање у светлим примерима немањићке традиције. Још у средњевековном периоду, омеђен законима који су забрањивали право наследства неправославним особама, Срби племићи, а касније и богати грађани желели су да своје имање положе за општу корист, те су својим тестаментима или завештајним писмима установили посебне задужбине, фондације, закладе итд.

Завештајна писма и тестаменти имали су двојако значење. Са једне стране, била је то жеља завештавача да осигура правилно коришћење и управљање имовином како би се остварили главни циљеви и жеље задужбинара. Са друге стране била је то жеља да се сачува материјална супстанца завештале имовине, како би се осигурало несметано даље функционисање фондације. У временима када је српски народ живео вам своје матичне земље, под другом влашћу, задужбинарство је задржало своју етноцентричност, нарочито за Србе из Румуније у периоду између два Светска рата. Срби задужбинари су својом делотворном активношћу допринели нарочито очувању интелектуалног подизања српске омладине. Свакако најсјани период српског задужбинарства у оквиру Хабзбуршке монархије почива на светлим примерима племенитог Саве Текелије, Саве Арсића, Персиде Макри Стојковић, Јулијане Фунтуке, Лауре Чарнојевић итд. А њиховом примеру следе други угледни грађани Срби који су своје име урезали у историју опстанка српског народа и његове духовне, интелектуалне и културне еманципације у мултиконфесионалном, мултиетничком и мултикултуралном Банату, као периферној области битисања српског народа.

Век који је уследио барокном периоду одговара прекретници у историји српског задужбинарства, јер од сада се задужбине остављају васцелом српском народу, а не појединцима. То је био уједно и позив упућен свим осталим друштвеним слојевима, нарочито породицама без потомака, да следе њиховом примеру. Одређујући циљ, задатак, структуру и смер својих задужбина, завештатељи су дубоко били укорењени у српском националном програму у датом месту и времену. Радити мукотрпно читавог живота и стицати богатство и све то одједном и великодушно оставити своме роду, могли су да ураде само ьуди дубоких патриотских осећања, свесни националних интереса, цицьева, стремљена и, надасве, интереса и потреба свог народа ${ }^{4}$.

етнички идентитет Срба у Мађарској на крају ХХ века, САНУ, Етногртафски институт, посебна издања, Књига 64, Београд, 2008; Мата Косовац, Српска православна митрополија карловачка према податиима од 1905. године, Сремски Карловци, 1910;

${ }^{4}$ Славко Вајиновић, Задужбинарство код Срба, Вукова задужбина, Београд, Прометеј, Нови Сад, 2012, стр. 8 
Српске привилегије, међу којима и право наследства, а које је касније законом овековечено и правно гарантовано, царским рескриптом из 1868. године, као законском одредницом, пружена је српском народу и завештатељима могућност да пред државним законом осигурају своје имање и добију гаранцију поштовања завештајних писама и тестамента. То је нарочито било важно за вероисповедно школство, које се у већини случајева издржавало из тих фондова. Од велике важности за задужбинарски покрет имао је пети законски члан поменутог рескрипта ${ }^{5}$. Нарочиту пажњу треба обратити чињеници да се у раскрипту јасно врши подела црквено-народних добара и добра фондација и заклада, које су Срби на основу добивених привилегија могли да их оснивају. На тај начин завештавачи су били у могућности да своју имовину поклоне цркви и да она временом постане црквена својина, или да оснивају задужбине а црквеним одборима да стављају у дужност администрацију ових добара.

У већини случајева администрацију добара, завештатељи су остављали црквеним општинама или појединцима, угледним грађанима или народним правницима. Међутим, не можемо говорити о јединственом профилу завештатеља и намени његовог завештања. Већина завештавача је ово племенито дело чинило из чисто верских и националних побуда. Тестаменти или завештатељна писма обично почињу присећањем на пролазност човечијег земног живота, а завршавају се чежњом за вечити спомен, како међу својим ближњима тако и пред Светим Олтаром. Тако на пример завештавачи остављају своме роду и својој иркви а за спомен душе покојних чланова породице или покој њихове душе. Нема сумње да су племенита и духовна прожимања била главни покретач њиховог подухвата, али је у томе одлучујућу улогу играла и жеља да се име и породична част отргне од заборава и овог и оног света.

О функционисању ових фондација, иако подчињене управи црквених општина, је испрва бринуо епархијски административни одбор и Српски православни народно црквени саборски одбор. Дописом др Георгија Зубковића, конзисторијског бележника под сигнатуром АД 1466/ 1912, стиче се утисак да је даљу бригу о овим фондовима водила искључиво епархијска конзисторија. У појединим случајевима, чак су се и завештавачи позивали на ауторитет црквене високе јерархије и црквено-народног одбора као гаранцију правилног руковођења фундација. Сава Текелија или породица Телечки су за себе и чланове своје породице задржали право на увид у рад њихових фундација, али у већину случајева црквене општине су именовале своје чланове као администраторе ових фундација, што је било повезано са особитом чашћу да неко руководи такву добротворну активност.

\footnotetext{
${ }^{5}$ Мита Клицин, Уредба о уређењу црквених школских фундационих дела грчко источне Српске митрополије одобрена Краљевским рескриптом од 10 августа 1868. године са изменама, допунама и важнијим одлукама средишњих автономних органа, Сремски Карловци, 1909, стр. 29-32
} 


\section{Главне одлике тестамента, опорука и „основатељних писама»}

Основатељна писма или тестаменти били су оубичајени документи у којима су завештатељи објављивали своју последњу вољу у погледу њихове покретне или непокретне имовине после њиховог упокојења. На тај начин од уложеног новца осниване су закладе или фундације, које су обично носиле име завештатеља, и одређивали и саму намену фундације.

У случају парастосуалних заклада, намена таквог фонда је била да се црквена општина стара о заупокојеним службама и о помињању чланова дотичне породице у пригодним данима и на пригодним местима (цркви, гробљу или капели). Неретки су били случајеви када је у овим случајевима црквеној општини било дато у бригу да се стара и о самом погребу завештатеља. Награде које су свештеници добијали зависили су од самог улога или завештајне своте. У појединим случајевима те су суме биле незначајне. У ту сврху црквени одбор темишварско- градске парохије на седници од 8/21 маја 1911. године, одлучило је да у будуће свештеницима припадају награде за парастосе сходно краљевском рескрипту, изузев оних случајева где се за парастосе и спомене или у тестаменту или основном писму излишно више не установљава.

Хуманитарне фондације или фондације од јавног интерес најчешће имају више осниваоца и приложника. Намена оваквих фондација је била да притекну у помоћ нарочито угроженим лицима, удовицама, сиромашним грађанима или сељацима, сиромашним ђацима итд. Сама намена ових фундација прописивала је изричите стандарде и услове. Тако на пример ђаци су требали да буду ваљаног понашања, са дорбим резултатима у учењу, доброг моралног владања, а сиромашна деца су припомоћ могла добити до напуњеног пунолетства итд.

Верске и васпитне фундације су најчешће биле намењене духовном и интелектуалном назидању ђака. Оне су имале за главне покровитеље имућније Србе, који су се већ истакли као мецене српске културе и духовности, те су и своје фундације оснивали уз црквене општине. Иако Црква није била директан власник фондације, ипак је црквеном одбору и високој црквеној јерархији уступљено старање око доброг функционисања ових фондова. Тако је предикална фундација Саве Текелије или задужбинарска активност Лауре Мочоњи била у чврстој вези са животом и радом православне цркве.

Оснивачи ових фондова су најчешће поклањали део или целу покретну или непокретну имовину. Тестаменти су најчешће објављивали вољу завештавача о начину поделе своје непокретне имовине, као и о начину $p y$ ковањ $а$ њоме (администрацији). Ово је најчешће било у оним случајевима где је завештавач остављао за собом незбринуте чланове своје породице, а којима је хтео обезбедити материјална средства за живот. Новчани прилози су често полагани на чување у познатим градским штедионицама. Воља 
тестатора је најчешће била да се не крњи главни део фонда, него да се од камате исплаћују принадлежности онима који су били директни корисници ових фондова.

\section{Сумарни опис фондација и фондова}

\section{Задужсбинарство}

- Задужбина Лауре племените Мочоњи, рођена племенита Чарнојевић. Из расположиве архивске грађе закључује се да је Лаура, као властелинка фенска, склопила два засебна уговора са фењском српском црквеном општином 8/20 маја 1885. године за подизање нове цркве и вероисповедне школе. Ове уговоре је касније потврдила и конзисторија Епархије темишварске под бројем AO 157/26 маја 1885. године 7 . Да би се одпочело зидање нове цркве и школе, спахиница је од црквене општине купила по два грунma земље по цени од 800 форинти (за сваки плац по 400 форинти). У уговору за зидања школе јасно је назначено да ће нова школа да се зида на грунту под бројем 270, на које се већ налазила школа али која цели подпуно не одговара. Лаура је на себе узела обавезу да симболично одкупи по цени од 400 форинти ову школу, али да речену своту не уступи црквеној општини, него да ту своту искористи за изградњу нове школе. Уз то у уговору је назначено да уколико би ново школско здање коштало више од ове своте, тај вишак би Лаура подмирила из сопственог трошка. По окончању радова, успосатвило се да је зидање школске дворане коштало 3.000 форинти, што је племенита госпожа уступила за школовање српске православне деце из места ${ }^{8}$

\section{Верске и васпитне фундације}

- $\quad \boldsymbol{B a c n u m н а ~ з а к л а д а . ~ Ј е д н а ~ о д ~ н а ј з н а ч а ј н и х ~ з а к л а д а ~ у ~ А р а д а , ~ о с н о - ~}$ вана је са циљем да се материјално помажу сиомашни ђаци. Основана је 1808. године у Араду, а међу оснивачима су били: Сава Текелија, Сава Арсић, Јован Александровић, Јован Бонтилоћ, Мар-

\footnotetext{
${ }^{6}$ Кориштена је искључиво архивска грађа која се налази на чување у Архиву Српске Православне Епархије темишварске

${ }^{7}$ Архив Српске Православне Епархије темишварске (АСПЕТ) - Фонд Закладе и фондаиије 1817-1922, кутија бр. 442

${ }^{8}$ Дабро-босански источник, Сарајево, бр. 23 за годину1889, стр. 366.
} 
ко Бабић, Сава Грујић, Атанасије Грујић, Лаза Еремић, Георгије Грујић, Јован Грујић, Димитрије Грујић, Михаил Јовица, Георгије Илић, Георгије Јанковић, Михајло Крестић, Емерик Константиновић, Теодор Љупшић, Георгије Михајловић, Јаков Мишић, Лаза Михајловић, Еменуел Пулио, Никола Поповић, Георгије Станковић, Петар Станојевић, Сава Секулић, Јован Танка, Коста Тодоровић, Павле Ђурски, Коста Александровић, Василије Антоновић, Никола Бабић, Петар Грујић, Георгије Грујић, Сава Михајловић, Димитрије Марко, Петар Маринковић, Никола Михајловић, Петар Николић, Петар Огњановић, Василије Петровић, Павле Поповић, Константин Пулио, Александар Радивојевић, Георгије Секулић, Лаза Сечански, Димитрије Станковић, Атанасије Чучан, Димитрије Крестић, Гаврило Јанковић, Игња Кремер, Јован Секулић, Андрија Антоновић, Ђорђе Марко и Јова Грујић. Међу даљим приложницима су били: наследници Јована Животића и Јована Јовановића, удовице Јовановић и Клајић, Мита Бугарин, Ђорђе Јанковић са супругом, Сава Ђорђевић, Никола Недељков, наследници Гавре Путерића, Ђорђе Бота, Сима Парванов, Лаза Стојан, Мита Богдан и месна црквена општина. Године 1881 закладом су руководили Димтрије Крестић, Гаврило Јанковић, Игњат Кремер, Јован Секулић, Андрија Антоновић, Ђорђе Марко и Јован Грујић. На основу закључка епархијског школског одбора, изумирањем, исељењем, оставком или губитком својства дотадашњих чланова, руководство ове закладе препуштена је месном школском одбору. Приходи од ове закладе би се и даље употребљавали искључиво за финансирање једине српске православне народне школе из места. Јадна од најважнијих одредаба односила се на евентуални престанак функњионисања месне српске школе. Чланом 4 одређено је да у случају да српске православне ирквене општине арадске временом нестане, Заклда васпитног школског завода прелази у руковање високославног српског саборског одбора са тим определењем да се из прихода установе штипендије, у првом реду за потомке негдашњих арадских, а ако ових не би било, поморишких, или у опште православних Срба у Аустро - Угарској монархији. Крајем 1908. године у готовом новцу заклада је поседовала 69 круна, у арадској штедионици 11.512 круна, а позајмљено разним лицима свега 29.510 круна. Заклада је имала и своју некретнину (улица Граница, бр. 20, бр. Грунта 1093), намењена школи чија је вредност исте године износила 6.930 круна.

- Заклада Софије Павловић рођене Шкарлато. Основана је 16 фебруара 1869. године а састојала се од стипендијског дома у улици Евгенија Савојског бр. 70. Правилник ове закладе положен 
је на чување у архиви слободне краљевске вароши Темишвара и садржи 21 ставку. Зевештатељка изричито напомиње да је заклада намењена за изучавање српске младежи, а дом који имовину ове шттпендије сачињава, водиће име „Штипендијски дом Софије Шкарлато-Павловић” (члан 1). Пошто је зграда била у лошем стању именован је Евгеније Рајић за извршитеља овог тестамента и упућен да узме хипотекарни зајам за оправку зграде, а за исплату овог зајма де се користи половина прихода који су намењени стипендијама, све док се зајам не исплати (члан 2). Циљ ове закладе је био да се потпомаже доброг владањ а и добро учећа се српско православна младеж (члан 3). Стипендијском закладом руководили су тројица најстаријих чланова темишварско градске црквене општине, које би црквена скупштина тајним гласањем изабрала (члан 4). Њихови мандати су ограничени на 6 година, а њихова дужност престаје у случају немарности или ако би који од њих престао бити члан градске парохије (члан 5). Њихове дужности су да врше администрацију над овим добром и да годишње објављују приходе и расходе ове закладе и подносе их црквеном одбору на одобрење (члан 6). За билокакве штете нанете овом фонду због немарности одговорна лица сносила би сву штету (члан 7) а цело пословање око бриге овог фонда било је добровољно и без икакве новчане надокнаде (члан 8). Особе именоване да руководе овом закладом биле су дужне да исплаћују редовне стипендије; осим редовних стипендија, Јозефи Кијурски, рођеној Андреовић припадала је и доживотна накнада од 120 форинти (члан 9). Стипендија би се исплаћивала стипендистима у месечним ратама (члан 10), а право на стипендију стицало би се пријављивањем на конкурсу (члан 11). услови да се неко пријави на овом конкурсу били су да је дете навршило 10 година, да је доброг здравља и да је преболео дечије болести (кравље богиње), да похађа темишварску гимназију, или билокоју реалну, трговачку или занатлијску школу са добрим резултатима, да има добро морално владање и да потиче из сиромашне породице. Приоритет су имали ђаци који потичу из темишварских сиромашних породица, а ако таквих не би било онда би се њихов број попунио са српским ђацима из околних места (члан 12). Стипендисти су имали обавезу да слушају науке у Темишвару, а са посебним одобрењем црквеног одбора и у другим школама ван Темишвара (члан 13). У случају да стипендисти покажу добре резултате у учењу постојала је могућност да ова задужбина продужи стипендију за даље школовање и да је сразмерно повишује, и то: 200 форинти за полазнике препарандије, 300 форинти за полазнике богословских школа и 400 форинти за 
полазнике трговачких и техничких школа, као и народних свеучилишта (члан 14). Непосредни надзор над стипендистима врше чланови управе стипендијског фонда (члан 15) и они су дужни да воде бригу и о духовном назидању стипендиста (члан 16). Право на стипендију би се губило због неморалног владања, неуспеха у школи, побољшање материјалног стања родитеља или ако родитељи или место из кога потичу стипендисти изнађу могућности за даље финансирање њихових студија (члан 17). Да би доказали своје успехе у школовању стипендисти су били дужни да приложе сведоџбе (члан 18) и да непрестано буду у контакту са својим старатељима (19).

- Предикална фундација (проповеднички фонд) др Саве Текелије. Ову фондацију је основао Сава Текелија а намењен је свештенослужитељима Текелијине цркве из Арада. Фонд је установљен 14 јануара 1811. године у Араду. Главна сума овог фонда износила је 1.000 форинти, које је Текелија приложио арадској црквеној општини, под условом да се ова сума положи у штедионицу и да се од камате овај фонд издржава. Главна одредба овог фонда односила се на свештенике који проповедају на литургијама у храму Светих Апостола Петра и Павла у Араду, а које да црквени тутори сваком приликом награђују са по пет форинти, а у случају да главни фонд се удвостручи, онда би тутори могли исплаћивати награду свештеницима до 10 форинти. Фондација је била активна и у међуратном периоду. Године 1927 у готом новцу је имала 200 леја, у штедионицама 3.180 леја, позајмљено 5.000 леја а као ратни зајам уступљен држави 1.000 леја. Исте године фонд је остварио приход од 916 леја, који је положен на чување Кредитној банци (Banca de Credit). Овом фундацијом су управљали благајници српске цркве из Арада према личном нахођењу, пошто фундација није имала сопствени правилник. Касније се овој фундацији придружили и други Арађани попут удове Видуловић и наследници покојног Петра Мокуце.

- Легаm Сузане Ризнић. Овај фонд основала је Сузана Ризнић и намењен је месном народном учитељу. Главни фонд износио је 2.100 круна, а од годишње камате месном учитељу су исплаћиване по две полугодишње рате у изосу од 42 круне. Овим фондом руководила је црквена општина темишварско градска.

- Фонд Севера Веселиновића и Јудите, рођене Чоков. Основан je 28.05./10.06 1917. године у Сараволи. После оснивања фонд је променио свој назив у Фонд за сараволску сиромашну, српску и школску деиу. Фонд је основан са сумом од 2.000 круна које су 
уложене као ратни зајам. Камата са првих десет година остао би у штедионици, а када би главна сума достигла 3.000 круна, тада би се годишње могло трошити по 120 круна од камате. Осим помагања српске и школске деце, црквена оптшина је била дужна да од речених 120 круна спреми и годишњи парастос породици Веселиновић о празнику Светог Николе. Изричита жеља осниваоца је била да се у овом фонду осим њихове почетне суме новца и камате не улаже са друге стране.

- Заклада Мише и Катарине Телечан. Основана је после упокојења Мише Телечана 6 маја 1905. године. Главни део овог фонда, од 600 круна, Миша је положио још за живота на рачун српске цркве из Арада 1898. године. На поменуту суму, његови наследници, тојест ћерке Хермина и Мила, као и зет Арсеније Илић приложили су суму од 2.000 круна које ће бити намењене функционисању ове закладе. Према жељи завештатеља речене суме ће бити положене на чување арадској штедионици, а када се буде уможио овај фонд од камате и буде достигао 10.000 круна, онда би се годишње исплаћивале стипендије српским ђацима у износу од 300 круна. Породица Телечан је задржала за себе право увида у рад ове фондације, али је оставила слободу арадској црквеној општини да повисује број стипендиста или своту стипендије у зависности од прилика.

- Кузмановићева стипендијска заклада. Основана је тестаментом Ђорђа Кузмановића из Меленаца 22 децембра 1880. године. Будући Кузмановићев завод основан је са главним прилогом од 600 круна, који је омогућавао школовање једног стипендисте. Стипендија би се издавала једном српском ђаку који се налази у средњу стручну школу или гимназију. Будући стипендисти ове закладе могу бити само Срби православне вере из Земаља Круне Светог Стефана, сиромашни, доброг владана и врло доброг успеха у наукама, здрави, слушаочи средњих, стручних или великих школа. Стипендију може ужсивати стипендиста од почетка његових средњошколских стручних или виших наука до свршетка средње стручне или више школе а губи право на стипендију онај стипендиста, који било у владању или наукама покаже слаб успех а на највишим школама не буде испите на време полагао. При једнакој квалификацији имају првенство деца родитеља који станују у Меленцима. 


\section{Хуманитарне фундације}

- Фундација „Сиротих Удова”. Ову фундацију су основали Срби из Арада ${ }^{9}$ и наменили су удовцима и удовицама. Капитал ове фундације износио је 1927. године свега 2.538 леја од којих је 500 леја било уступљено као ратни зајам. Године 1927 фундација је имала свега 484 леја прихода а њом су управљали црквени благајници пошто није имала сопствени правилник.

- Легат Ђорђа Предовића. Фонд у износу од 1.624 круна основао је Ђорђе Предовић и наменио га је за милостињу српским и румунским житељима из Темишвара Фабрике.

- Фундација Cироте учеће се деце. Основали су је Срби из Арада и наменили сиротим ђацима. Међу оснивачима су били Теодор Литричин, Марија Бота, Миша Крачун и црквена општина арадска.

- Марковићева фундација. Основана је у Араду, а каснији приложници су били Софија Бота и Арсеније Петровић.

- Заклада Mите Рошуловића. Закладу је основао угледни чаковачки Србин, Мита Рошуловић 13/25 фебруара 1889. године у Чакову. У тестаменту он вели да $y$ колико је по природном току живота човечијег смрт неизвесна, но час њен неизвестан: то побућен чувством свете дужности при здравом разуму и после зрелог и озбиљног расуђења, за случај смрти овим следеће за моју слободну тврду последюу вољу изјављујем. Душу моју препоручујем милости свемогућег Бога, а погреб мој остављам на увићавност мојих наследника. Својим тестаментом Мита Рошуловић је завештао српској цркви из Чакова покретну и непокретну имовину у Чакову (кућу са два ланца баште бр. 114, 69 ланца ораће земље под грунтовним бројем 104, кућу на главном тргу под грунтовним бројем 569, кућу и башту по бројем 653) и Петроману (44 ланца оранице под грунтовним бројем 35, 1 ланац оранице под грунтовним бројем 94, 8 ланца оранице под грунтовним бројем 479, 6 ланца оранице под грунтовним бројем 539, 7 ланаца оранице под грунтовним бројем 547). Тестаментом је предвиђено да се прве две куће у Чакову не могу продати, а остале некретнине, ако црквена општина чаковачка нађе за сходно може их продати. Од покретне имовине, после његовог упокојења основао се Фонд Мите Рошуловића за издржавање српског православног свештеника и сриског вероисповедног учитеља чаковачког. Чаковачка парохија као званични наследник Мите Рошуловића, била је дужна да годишње исплаћује по 400 форинти његовој сестри Агници, удатој Чарнић и брату Ники за њихово издржавање, с тим што би они живели до

\footnotetext{
${ }_{9}^{9}$ Међу њима Марија Сусан, Јелена Нешин, Ђорђе Михајловић.
} 
упокојења у поменутим кућама у Чакову. Тестаментом је одређено да његови рођаци наследе после његовог упокојења и извесне суме новца, као што следи: нећацима/ синовцима сестре Агнице, Јоци и Владимиру, 2.500 форинти до навршене 28 године, нећацима/ сину и ћерки покојне сестре Јулијане, удате Немет, Душану и Јелени по 1.000 форинти до пунолетства, кћери и сину шогорице Драге Костић, Марији и Јоци Шумарски 2.000 форинти, деци шогора Пере Николића, Зорки, Ники и Косари, по 500 форинти до пунолетства. За извршитеља овог тестамента именован је чаковачки трговац Михајло Панић.

- Заклада Велинке Росић, рођене Жикић. Основана је 1924 године приликом даровног уговора Велинке Росић из Кетфеља, којим је ова поклонила више некретнина месној црквеној општини. Непокретна имовина од 3 јутра земље коју је уступила цркви, могла је да се користи сходно својој намени, с тим што би продаја или билокакво добровољно одстрањивање било забрањено. Заузврат кетфељска парохија била је дужна да спреми парастос за покој њене душе о празнику Цвети.

- Легат Ђуре и Стефаније Савић. Основан је 29 јула 1919. године. На основу тестаментарне опоруке породица Савић приложила је на чување штедионици Срстер из Темишвара суму од 1.000 круна на име темишварско фабричке црквене општине, с тим да се за покој њихове душе служи годишњи парастос о празнику Ђурђевдана.

- Заоставштина Ђоке Николића. Основао је 3/16 јануара 1916. године становник Кнеза, Ђока Николић. Главни део заоставштине биле су некретнине: 1 јутро ливаде у Селишту (бр.гр. 1335, парцела 2270), 1 јутро ливаде у Сикео (бр.гр. 1118, парцела 1715), 1 јутро оранице у Јарку (бр.гр. 1118, парцела 1851), 1 јутро оранице у Пакаи (бр. гр. 1118, парцела 1931), 1 јутро оранице у Немачкој дољи (бр.гр. 1118, парцела 2733), 2 јутра ливаде у Сикео (бр. гр. 336, парцела 1629), 600 хвати винограду Излазу (бр. гр. 336, парцела 767), 800 хвати винограда у Излазу (бр.гр. 586, парцела 673). По његовој жељи овом имовином би после његовог упокојења руководити црквена општина из Кнеза, а рачуне би сваке године подносила на одобрење епархијској конзисторији. Заузврат ове даровнице, црквена општина је дужна да о празнику Светог Николе одржи парастос породици Николић, а као награду за чинодејство црквена општина је била дужна исплатити по 8 круна свештенику, 2 круне учитељу и 1 круну црквењаку.

- Легат Катице Надашке. Овај фонд је основао Јован Дронка у Малом Бечкереку, а за успомену на његову покојну мајку Кати- 
цу Надашки, 15/28 децембра 1913. године. Закладни иметак износио је 400 круна и положен је у темишварску штедионицу. Из годишње камате сходно његовој вољи црквена општина је била дужна да годишње о празнику Свете Параскеве служи помен његовој покојној мајци.

- Заклада Стеве Станојева. Основао је Стева Станојев из Иванде 1908. године када је иванђанској црквеној општини поклонио 2 јутра земље.

- Заклада Александра Крајника. Основана је 9 децембра 1900. године када је житељ темишварски Александар Крајник тестаментом утврдио каква ће судбина његове покретне и непокретне имовине бити после упокојења. У ту сврху материјална добра је положио на чување Првој темишварској штедионици (бр. 45869 и бр. 45870) и у Темишварској аграрној штедионици (бр. 21894). Од главне суме одредио је: 800 круна за његов погреб, од којих половина црквеној општини темишварско градској ${ }^{10}$. Осим тога да буде оглашен у свим српским црквама из Темишвара, а после сахране да се постави бели мермерни крст на његовом гробу који заједно са натписом да не кошта више од 100 круна. Приликом сваког парастоса да се исплате уобичајене суме, а црквењаку Глиши Журановићу да се исплати почасна награда од 20 круна. Од остале суме новца одређено је да се утроши 400 круна за жељезну ограду око гроба, а од осталих 5.000 основати закладу са његовим именом. Такође поменуто је да се одржавају годишњи помени за његовг оца Мојсу, мајку Ану и сестру Анастасију. Овом опоруком оставио је 4.000 круна његовом рођаку Шандору Панићу из Бранешта, Марији Ранков, рођеној Бугарски, 1.700 круна, Глиши Журановићу 200 круна, Јелисавети Сабади 150 круна, удовој Ђорђевић, рођеној Басараба 100 круна и Гиги Младеновићу 100 круна. Сва материјална средства која су се налазила на чување код аграрне штедионице, намењене су саборном храму из Темишвара, а извршитељу тестаментарне опоруке др Димитрију Стефановићу да се исплати награда од 1.000 круна.

- Леzат Јована Јовановића. Установљен је тестаментарном опоруком Јована Јовановића, житеља фабричког. Главне одредбе овог тестамента налажу да се из његове заоставштине преда по десет форинти варошкој болници, темишварском сиротишту и фондацији куће Златни јелен. Здање Златни јелен, као посебну фондацију, оставио је за издржавање своје супруге Пелагије, а после њеног упокојења, фондација, која је уједно и власник овог здања,

\footnotetext{
${ }^{10}$ Одређено је да на сахрани чинодејствују четири свештеника и ђакон, да сваки појединац добије по 20 круна, учитељ 6 круна, црквењак 5 круна.
} 
да користи приходе искључиво за потребе храма Светог Георгија у Темишвару Фабрици.

\section{Парастосуалне закладе}

- Заклада Мите Поповићa. Темишварски грађанин Мита Поповић основао је ову закладу 16 августа 1893. године, када му је било 71 година. Главни фонд ове закладе састојао се у половини ланияа винограда са једном колибом и осталим покретним стварима ... у сандуку книжииу од старе темишварске штедионице са уложенuх до 1.600 ф. Приликом оснивања ове закладе тражио је да се од речене своте достојно сахрани од стране српског православног свештеника из Темишвара. Виноград са пропратним зградама оставио је такође управи темишварско градске парохије. Као извршитеља његове закладе именовао је протопрезвитера Кузмана Станића. Као сведоци именовани су Кузман Станић, прота Сава Николић, Стеван Шербан, Ђорђе Звекић и Кершек Ђула.

- Парастосуална заклада Јулијане Маргетић, рођ. Чакован. Јулијана, власница куће под бр. 9 у Замак - улици у унутрашњем граду оставила је 400 круна катедралном храму у Темишвару да се од камате пола легата издаје за увек пароху 4 круне, а да овај сваке године на Петровдан у својим молитвама спомене Петра, Марију, Јована и Јулијану. Уколико ова њена опорука не буде испоштована онда би се овај легат уступио Цркви Светог Великомученика Георгија из Темишвара Фабрика. Ова заклада основана је пре 1902. године.

- Парастосуална заклада Розе Стевановић, рођ. племенита Ђуричко од Модоша. Дана 28 септембра 1902. године Коста Стевановић, као извршитељ опоруке своје покојне мајке Розе, уступио је управи темишварско градске парохије суму од 400 круна као главнииу са том молбом, да се уз употребу годишњих камата од те главнице сваке године 6 октобра по старом, 19 октобра по новом, ако то јест Томин дан у недељу пада, у противном случају у недељу после Томин дана за време Свете Литургије помен за следеће личности учинити, и то: за Тому, Розалију, Бранка и Павла Стевановића. Од годишње камате предвиђено је да буду награђени свештеници и црквено особље које присуствује на чинодејству. Године 1902 одлучено је да се цео фонд уложи у штедионицу те да се сваке године у смислу опоруке на горепоменути начин употреби.

- Парастосуална заклада Јулијане Станић. Супруга покојног окружног протопрезвитера Кузмана, Јулијана Станић, основала је 
парастосуалну закладу и тестаментом одредила да се на дан Свете Јулијане одржи пригодан помен, а свештенику који чинодејствује да му се исплати као награда по 5 круна. Уз то напоменуто је да се одржи и помен за њеног супруга Кузмана и сина Миливоја.

- Парастосуална заклада Александра Крајника. Житељ темишварски Александар Крајник основао је парастосуалну закладу од 5.000 круна почетком 1900 године. У опоруци тражио је од темишварско градске парохије да му се одржи парастос 20 септембра, 14 маја и 30 августа. Од годишње камате 1907. године исплаћено је 66 круна особљу које је било присутно на парастосима и то: темишварском проти 10 круна, капелану, 6 круна, ђакону 6 круна, учитељу појцу 6 круна, другом појцу 4 круне, паскурњачи 4 круне, црквењаку 2 круне, звонару 2 круне, сиротињи 1 круну, Светој Цркви 10 круне, за кољиво 10 круне.

- Парастосуална фундација. Фондацију су основали 17 завештавача ${ }^{11}$ приложивши при оснивању разне износе у новцу. Године 1927 капитал фундације износио је 7708 леја од којег је у штедионици било 3548 леја, позајмљено 4000 леја а у готовом новцу свега 160 леја. Исте године фундација је имала свега прихода у износу од 2027 леја.

- Легат Јулијане Фунтуке рођена Макри. Овај фонд основала је Јулијана Фунтука, рођена Макри и наменила је за помоћ сиротињи и за одржавање годишњег парастоса члановима њене породице. Цео износ од 8400 круна је положен на чување у Прву темишварску штедионицу, а 1907. године камата је износила свега 339 круне. Исте године, сходно завештатељкиној жељи од добивене камате сиромашним породицама уступљено је 277 круна на Велики Петак а за спремање парастоса 62 круне. Овим фондом руководила је црквена општина темишварско градска.

- Заклада Милоша Јаковљевића. Ову фундацију је основао немећански ратар Милош Јаковљевић 11/24 јуна 1900 године. Тада је тестаментом месној цркви оставио 800 круна са жељом да се његово име и имена својих преминулих помињу на парастосима и на други дан Васкрса. Према тестаменту којег је приложио, главни део капитала није могао да буде умањен, а од годишње камате да се исплаћује немећанском свештенику по 6 круна, и учитељу по 4 круне за богослужење и помен покојних чланова породице Јаковљевић. Као главне руководиоце ове закладе именовао је управу немећанску пархоји која је била дужна да испуњава услове поменуте у тестаменту. Цела свота је уложена у Прву темишварску штедионицу а крајем 1911. године овај фонд је износио 1247

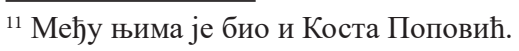


круне. На основу жеље завештавача, црквене општина назвала је ову фондацију Парастосуална заклада Милоша Јаковљевића. На основу закључка епархијске конзисторије, одобрено је 1912 године да од вишка камате, уколико је могуће, да немаћанска црква купи једно катастарско јутро земље. Тестамент је исписан руком месног пароха Миливоја Јовановића, а поред завештатеља, потписали се као сведоци житељи из Немета: Сима Радулов, Никола Стојков, Јован Мурар, Милош Ђурин и Сава Филипов.

- Парастосуална заклада покојног протојереја Трифуна Бранковића пароха фабричког. Овај фонд основао је епископ Димитрије Бранковић у спомен свога родитеља покојног фабричког пароха Трифуна у износу од 4000 леја које је поклонио темишварско фабричкој црквеној општини. Цела сума је положена на чување темишварској Српкој штедионици. За трошкове око спремања парастоса и награде особљу које присусутвује парастосу (свештенику 60 леја, појцу 25 леја, црквењаку 25 леја, гробару 75 леја, сиротињи 15 леја) има се подмирити из годишње камате. Осим тога епископ Димитрије је одредио да место уобичајеног куваног кољива има одржати парастос над прописним кољивом као што се следи: у малу чашииу има се усити жито и у жито уметнути запаљена свећииа, а после одслуженог парастоса исто жито на гробу покојниковог при малом помену просут. Гроб покојника и крст на гробу има се стално у чистоти и у реду одржати, гроб се има зеленилом засадити, а крст чувати да се пропадне и падне.

- Парастосуални фонд покојног Живе Глувачког и Марице рођене Божсидар из Tорње. Овај вонд је основала Марица Глувачки из Торње. Сврха овог фонда је била да се од главне приложене суме до 400 круна и годишње камате спрема парастос породици Глувачки у храму Рођења Пресвете Богородице из Торње. Приликом служења парастоса од годишње камате би се платило свештенику 6 круне, учитељу 2 круне, појцу 1 круна, црквењаку 1 круна, а за спремање кољива по 3 круне. Ако би поред ових дуговања остало више од камате, онда би се то додало главној суми као приход.

- Заклада Паје Петровог. Даровни уговор између кетфељске црквене општине и Паје Петровог одобрен је од стране епархијске конзисторије 1924. године. Овим угоговором завештатељ је поклонио кетфељској парохији 4 јутра земље. У замену за ово доброчинство кетфељски пароси би у будуће били дужни да за празника Свете Параскеве служе парастос за покој његове душе и супруге му Милеве, рођене Јованов. На сам дан помена црквена општина је дужна да набави велико кољиво, свеће свима одраслима који се налазе у иркви, да награди свештеника за држање парастоса и 
парусије по штоли наређене од Епархијске Конзисторије, једног појца са половином штоле као што је прописано свештенику, да другог дана Ускрса гроб напред именованих са вином прелије и на гробу раздели један колач. Као извршитеље ове опоруке именовани су чланови парохијског одбора кетфељске парохије, а рачуне од прихода ове земље да одобрава конзисторија Епархије темишвараске.

- Парастосуална заклада Милана Тешина бившег диьашанског становника. У смислу тестаментарне опоруке житеља Дињаша, Милана Тешина од 23 децембра 1907. године, тачка 5 одрежени су услови оснивања ове закладе: Још осталих код горепоменуте задруге уложених 2000 круна, речима две хиљаде круна, остављам дињашкој православној српској иркви. Црквена општина може са овом свотом слободно руковати, то јест ја јој ову на слободно расположене дајем, но са тим упутством, да је дужна сваке године у цркви о зимњем Светом Николи за покој душе моје и мога сина Миливоја парастос држати, а о летьем Светом Николи дужна је ирквена општина за нас обоје помен држати. На седници црквеног одбора дињашанске парохије од 1 фебруара 1910. године, чланови одбора су се лично обавезали око старања и дословног извршења одредбе ове опоруке.

- Заклада Младена и Стефаније Фелић из Кетфеља. Основали су је велики добротвори кетфељске парохије Младен и Стефанија Фелић, који су месној цркви поклонили четири велика звона у вредности од 280.000 леја, 1928. године. Кетфељска црквена општина обавезала се да на дан Светог Јована одржи парастос породици Фелић, да одржава у реду њихове гробове, а за тачно извршење овога именовани су у будуће чланови црквеног одбора.

- Заклада Хермине, удове Николе Адамовића. Хермина Адамовић, ћерка Мише и Катарине Телечан основала је 30 октобра 1916. године ову закладу у Араду из љубави према Светој вери српској православној и према овдашњој Светој српској иркви храма Светих Апостола Петра и Павла, у којој сам критена и са својим блаженоупокојеним супругом венчана и у којој топлим молитвама и примана Свете Тајне исповести и причешћа за спасеније своје душе и ниже поменутих тежим. Главни фонд ове закладе чини сума у износу од 2000 круна која је положена на чување у арадску штедионицу 8 новембра 1916. године. Главна опорука завештајног писма ставља у дужност арадској парохији да се и празнику Светог Архангела Михаила сваке године држи парастос за покој њене душе, као и покој њене сестре Марије Миле, удату Илић и њеног супруга Арсенија. Осим уобичајених награда свеш- 
тенику, учитељу и црквењаку за чинодејства приликом парастоса, намењен је и фонд за издржавање сирочади. Брига о овој заклади уступљена је Српском православном црквено школском одбору, а у случају нестанка црквеног одбора, онда би бригу о овој заклади преузео Црквено народни сабор.

\section{Епилог}

Период после Другог светског рата имовине ових фундација, па и саме фундације претрпеле су велике штете. Многе зграде и непокретна имовина биле су реквириране у корист ,општег добра” а новчана средства из којих су се фондације издржавале изгубила су своју вредност. Елементарне поправке на овим преосталим зградама било је нужно чинити, те су ради тога подизани зајмови. Стипендије су нередовно исплаћиване, а имена ових добротвора су свештеници у тишини совјих храмова помињали на Светим Литургијама. Све је то ,допринело” да се задужбинарство угаси међу Србима, иако је оно понекад као блистава искра покушавала да пробије мрачни понор сурових времена. Данас се за захвалношћу и дивљењем говори о задужбинарству као изразитој љубави према сопственом народу и вери. Уједно ови светли примери постају отворен позив сваком добронамерном грађанину да своје име упише у овом својеврсном пантеону добротвора.

\section{Архивска грађа}

Архив Српске Православне Епархије темишварске (АСПЕТ) - Фонд Закладе и фондације 1817-1922, кутија бр. 442

\section{Литература}

Вајиновић, 2012: С. Вајиновић, Задужбинарство код Срба, Вукова задужбина, Београд, Прометеј, Нови Сад, 2012;

Милошевић, 2005: Р. М. Милошевић, Црквено задужбинарство код Срба, Храм Светог Апостола Луке, 2005;

Љушић, 1994: Радош Љушић, Србија ХІХ века, Војна књига, Београд, 1994;

Lupulovici, 2009: V. Lupulovici, Viața bisericească a sârbilor din Banat între anii 1865 - 1918, Presa universitară clujeană, 2009;

Марковић, Ђокић, 2020: М. Марковић, Н. Ђокић, Црква Празник Светих Апостола Петра и Павла (Петровдан) у Араду до Првог светског рата - прилог историји, у Митолошки зборник 43, Рача 2020, pp. 341-354; 
Прелић 2008: М. Прелић, (Н)и овде (н)и тамо: етнички идентитет Срба у Мађарској на крају XX века, САНУ, Етногртафски институт, посебна издања, Књига 64, Београд, 2008;

Косовац, 1910: М. Косовац, Српска православна митрополија карловачка према податиима од 1905. године, Сремски Карловци, 1910;

Клицин, 1909: М. Клицин, Уредба о уређењу ирквених шиклских фундационих дела грчко источне Српске митрополије одобрена Краљевским рескриптом од 10 августа 1868. године са изменама, допунама и важнијим одлукама средиињих автономних органа, Сремски Карловци, 1909.

Дабро-босански источник, Сарајево, бр. 23 за годину 1889.

Iasin Sasa

\title{
ENDOWMENTS IN SERBIAN ORTHODOX EPARCHY OF TIMISOARA
}

\begin{abstract}
Summary
Endowment as a possessed form of charity was very much present in the life of Serbian communities. Endowments are one of the best examples of an individual's love and respect for their nationality and for the spiritual and intellectual support of Serbian youth and intellectuals. The times that followed the Second World War diminished the public's interest in this type of charity, ie the fate of these funds became uncertain until they were extinguished. Today, when they are no more, the learned good deeds and the significance they had in life testify to them the most. Archival material, as well as other rich bibliography, provide a real opportunity to present the life of these endowments and their creators, as a phenomenon of exceptional importance in the Serbian people. Leaving their endowments to those who will come into the world after them, the endowments are permanently ugly. Conscious of their presumed role in a given time and space must not replace the work of those who, through self-preservation, love for the people and their neighbors and noble feelings, considered it our duty to publish their immortal deeds.
\end{abstract}

Key words: fundation, philantrope, Timisoara, Arad. 